Article

\title{
Eco-Friendly Fiberboard Panels from Recycled Fibers Bonded with Calcium Lignosulfonate
}

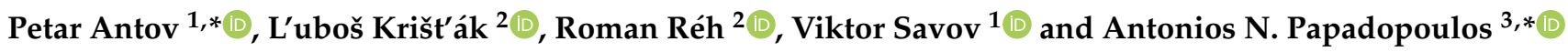 \\ 1 Faculty of Forest Industry, University of Forestry, 1797 Sofia, Bulgaria; victor_savov@ltu.bg \\ 2 Faculty of Wood Sciences and Technology, Technical University in Zvolen, 96001 Zvolen, Slovakia; \\ kristak@tuzvo.sk (L.K.); reh@tuzvo.sk (R.R.) \\ 3 Laboratory of Wood Chemistry and Technology, Department of Forestry and Natural Environment, \\ International Hellenic University, GR-661 00 Drama, Greece \\ * Correspondence: p.antov@ltu.bg (P.A.); antpap@for.ihu.gr (A.N.P.)
}

check for updates

Citation: Antov, P.; Krišt'ák, L.; Réh, R.; Savov, V.; Papadopoulos, A.N. Eco-Friendly Fiberboard Panels from Recycled Fibers Bonded with Calcium Lignosulfonate. Polymers 2021, 13, 639. https://doi.org/ $10.3390 /$ polym 13040639

Academic Editor: Gianluca Tondi

Received: 14 February 2021

Accepted: 19 February 2021

Published: 21 February 2021

Publisher's Note: MDPI stays neutral with regard to jurisdictional claims in published maps and institutional affiliations.

Copyright: (c) 2021 by the authors. Licensee MDPI, Basel, Switzerland. This article is an open access article distributed under the terms and conditions of the Creative Commons Attribution (CC BY) license (https:// creativecommons.org/licenses/by/ $4.0 /)$.

\begin{abstract}
The potential of using residual softwood fibers from the pulp and paper industry for producing eco-friendly, zero-formaldehyde fiberboard panels, bonded with calcium lignosulfonate (CLS) as a lignin-based, formaldehyde free adhesive, was investigated in this work. Fiberboard panels were manufactured in the laboratory by applying CLS addition content ranging from $8 \%$ to $14 \%$ (on the dry fibers). The physical and mechanical properties of the developed composites, i.e., water absorption (WA), thickness swelling (TS), modulus of elasticity (MOE), bending strength (MOR), as well as the free formaldehyde emission, were evaluated according to the European norms. In general, only the composites, developed with 14\% CLS content, exhibited MOE and MOR values, comparable with the standard requirements for medium-density fiberboards (MDF) for use in dry conditions. All laboratory-produced composites demonstrated significantly deteriorated moisture-related properties, i.e., WA ( $24 \mathrm{~h})$ and TS $(24 \mathrm{~h})$, which is a major drawback. Noticeably, the fiberboards produced had a close-to-zero formaldehyde content, reaching the super E0 class $(\leq 1.5 \mathrm{mg} / 100 \mathrm{~g})$, with values, ranging from $0.8 \mathrm{mg} / 100 \mathrm{~g}$ to $1.1 \mathrm{mg} / 100 \mathrm{~g}$, i.e., equivalent to formaldehyde emission of natural wood. The amount of CLS adhesive had no significant effect on formaldehyde content.
\end{abstract}

Keywords: wood-based panels; fiberboards; recycled fibers; bioadhesives; calcium lignosulfonate; zero-formaldehyde emission

\section{Introduction}

The resource efficiency optimization, and the transition to circular, low-carbon bioeconomy, have posed new requirements and actions towards a greater, more sustainable use of natural raw materials by sustainably increasing the primary production and conversion of waste into high-value added products. Cascading use of lignocellulosic resources, defined as "the efficient utilization of resources by using residues and recycled materials for material use to extend total biomass availability within a given system", is one of the leading principles for achieving this goal.

The wood-based panel industry, with its wide variety of products for a number of end-uses, such as construction and furniture manufacturing, is one of the fastest growing industries worldwide, characterized by a clear upward trend for many years [1-3]. In 2019, the annual global production of wood-based composites was estimated to be 357 million $\mathrm{m}^{3}$, which represents an increase of $268 \%$ compared to 1980 [4]. The possibilities to reduce the increased consumption of wood raw materials include recycling of waste wood-based panels at the end of their life cycle [5-10], utilization of alternative raw materials [11-15], and use of waste lignocellulosic materials [16-18].

Global pulp, paper, and paperboard production is also increasing, and in 2019, it was estimated to approximately 202 million tons, and 404 million tons, respectively, with USA and China being the major producers [4]. Consequently, pulp and paper facilities generate 
substantial amounts of non-hazardous sludge and solid waste, requiring further waste management or utilization as by-products $[19,20]$. Currently, the main methods of disposal of the primary sludge are landfilling or burning for energy generation. However, due to the stricter environmental legislation and increased landfilling costs in the EU, the industry is searching for alternative waste management methods.

Most of the suspended solids are removed during primary mechanical wastewater treatment, and the resulting liquid sludge contains large quantities of residual wood fibers as the main organic components $[19,21]$, thus representing a potential feedstock for manufacturing wood-based panels [22-24]. The residual fibers are significantly different in composition, even between factories using the same pulp and paper production technologies [25]. In addition, another distinct disadvantage for their wider utilization as a raw material is the significantly reduced lignin content [26].

Traditional synthetic adhesives, used in the production of wood-based panels, are usually made from petroleum-derived components, based on urea, formaldehyde, phenol, melamine, etc. [27-30]. Nowadays, approximately 95\% of the total adhesives used for manufacturing wood composites, are formaldehyde-based resins [31], with urea-formaldehyde resins being the most predominant type, with an estimated global consumption of 11 million tons/year [32-34]. Despite their numerous advantages of conventional synthetic thermosetting adhesives, such as excellent adhesion properties and water resistance, ease of handling, low curing temperature, short press times, relative cost-effectiveness, etc. [33,35-39], they have a major drawback, connected to the hazardous emission of free formaldehyde and other volatile organic compounds (VOC) from the finished wood-based panels [40-42], associated with environmental problems and a number of serious human health hazards, such as such as eye, skin, and nervous system irritation, skin sensitization, nausea, and even cancer [43-45]. In 2004, formaldehyde was reclassified as "carcinogenic to humans" (Group 1) by the International Agency for Research on Cancer [46]. This has led to the adoption of stricter legislative regulations on formaldehyde emission values from wood-based panels, which have gradually been lowered over time, resulting in increased consumer environmental awareness [47] and greater industrial interest towards the development of less toxic, eco-friendly wood-based composites, where the traditional thermosetting resins have been partly or completely replaced by renewable, bio-based adhesives [48-56], or by adding different organic [57-59] and inorganic [40,44,48,60-63] compounds to adhesives systems as formaldehyde scavengers. Another possible solution to avoid the negative effect of formaldehyde release from wood-based panels is to use isocyanate adhesives, namely polymeric $4,4^{\prime}$-diphenyl methane diisocyanate (pMDI), where no formaldehyde is added [33,64]. However, the relatively higher cost of pMDIs compared to the common formaldehyde-based adhesives and the need to adjust the glue lines [65] are the main limiting factors for their wider application as wood adhesives.

While the wood-based panel industry, mainly for reasons of supply, is still dominated by the traditional oil-derived adhesives, both in these fields as well as in the strongly upcoming field of bio-based adhesives, there has been almost incredible progress as well as developments dictated by the intellectual ferment induced by a number of outside constraints. These are the stricter government regulations to reduce and even eliminate formaldehyde and other materials that are to some extent toxic, consumer awareness and the consequent drive of industry to favor more environment-friendly materials and, finally, the drive of industry to decrease or even eliminate their dependence on petrochemicals, due to the real or imagined future decrease of oil reserves with its consequent increase in the price of raw materials for purely traditionally manufactured wood binders [66-68].

Recent developments in the field of sustainable, bio-based adhesives include the use of different renewable biomass feedstocks, such as proteins [69-73], starch [74,75], tannins [76-78], and lignin [17,79-84]. The development of alternative value-added wood composites that use waste materials or recycled materials is becoming beneficial due to over exploitation of natural resources. Nowadays, the products manufactured from recycled materials or by-products are especially paid attention in the view-point of environmental 
problems [85-89]. In this context, a good and representative example is the utilization of waste polystyrene as a binder in wood composites manufacture. This approach of retraining wood or wastes of wood and polystyrene obtained from packing remove from service permits to produce economic and environment respectful composites. Waste polystyrene poses serious environmental risks, especially in developing countries where disposal facilities are lacking and its management is a serious problem because it is easy to recycle. Its application as a binder in order to produce value-added wood composites avoids the environmental problems that formaldehyde adhesives cause. Masri et al. [90] successfully produced particleboards from date palm and expanded polystyrene (EPS) wastes and reported that the bending strength and stress reached acceptable values of 0.78 GPa and 2.84 MPa, coupled with good fiber-matrix interface adhesion. Akinyemi et al. [91] presented the results of the experimental study on the production of particle boards from wastes of wood and expanded polystyrene foam. This study demonstrated that wood and expanded polystyrene foam wastes are sustainable materials for producing composite wood-based panels that are still durable in a moist environment. Polystyrene has been also applied in the manufacture of lightweight gypsum-based composites [92].

Lignin is a highly-branched, polyaromatic macromolecule and the second most abundant organic material on earth after cellulose $[93,94]$. The structure of lignin is composed of different units and repeated structures, depending on the plant species, growing conditions, and duration, and the extraction method applied to separate lignin from hemicellulose and cellulose [95]. Currently, lignin is regarded as a waste or a by-product from the production of pulp, paper, and ethanol with an approximate annual production of 100 million tons worldwide [96], of which less than $2 \%$ is used for value-added applications, such as surfactants, adhesives, polymer reinforcement materials, dispersants, etc., while the rest is burnt for heat and energy $[51,96,97]$. Lignin contains different functional groups, i.e., hydroxyl, methoxyl, and carbonyl groups, which allow its chemical modification, applied to increase its reactivity. The polyphenolic structure of lignin is the main reason for its application in the composition of adhesives, mostly as a partial substitution of phenol $\left(\mathrm{C}_{6} \mathrm{H}_{6} \mathrm{O}\right)$ in phenol-formaldehyde resins [98].

The different technological processes, used in the pulp and paper industry to obtain lignin, include mechanical, chemical, and enzymatic methods, which subsequently produce different types of technical lignin, e.g., hydrolytic lignin obtained by enzymatic hydrolysis process [99], organosolv lignin by organosolv treatment [100], alkali lignin, derived by the Kraft process [101], and lignosulfonates, obtained by the sulfite pulping process [101]. Lignosulfonates (LS), produced by the reaction of sulfurous acid $\left(\mathrm{H}_{2} \mathrm{SO}_{3}\right)$ and a sulfite $\left(\mathrm{SO}_{3}{ }^{2-}\right)$ or bisulfite salts $\left(\mathrm{HSO}_{3}{ }^{2-}\right)$, comprising ammonium, sodium, calcium, or magnesium at varied $\mathrm{pH}$ levels [102], are available in large quantities, with an estimated global annual production of 1 million tons [103]. Due to the availability of sulfonate group, LS are water soluble. The relatively high molecular weight of LS, ranging from $1000-150,000 \mathrm{~g} \cdot \mathrm{mol}^{-1}$ [103], is another important factor affecting the performance of LS in adhesive applications. Therefore, additional chemical modification of LS, such as hydroxymethylation, can be applied to increase their reactivity $[102,103]$. The major drawbacks for the wider industrial application of LS in the composition of wood adhesives is the increased hydrophilicity of finished wood-based panels and longer press times $[17,81,89]$, which can be resolved by using suitable cross-linkers $[79,104]$ or by optimizing the production parameters [105].

The aim of this research work was to investigate the potential of producing ecofriendly fiberboard composites from residual wood fibers from the pulp and paper industry, bonded with formaldehyde-free adhesive, namely calcium lignosulfonate, complying with the European standards.

\section{Materials and Methods}

Residual fiber mass, a mixture of the softwood species Scots pine (Pinus silvestris L.) and Norway spruce (Picea abies Karst.), oven-dried to $11 \%$ moisture content, was used in 
this work. The industrial waste fibers were supplied by the Bulgarian pulp and paper factory Mondi Stambolyiski EAD. The fiber mass, comprised of untreated, broken wood fibers and fine cellulose fibrils, had a bulk density of $28.49 \mathrm{~kg} \cdot \mathrm{m}^{-3}$. The residual fibers had lengths from 520 to $1150 \mu \mathrm{m}$ and a reduced lignin content of approx. $7 \%$ (factory data).

Calcium lignosulfonate (CLS) at $8 \%, 10 \%, 12 \%$, and $14 \%$ (based on the dry weight of fibers) was used as a binder. The CLS (lignosulfonic acid calcium salt, CAS No. 8061-52-7) additive used was in the form of amorphous yellow-brownish water-soluble powder with the following characteristics: total solids content: $93 \%$; calcium content: $6 \%$; reduced sugars: $7 \%$; ash content: $6 \%$; acidic factor in $10 \%$ solution: $\mathrm{pH}=4.3 \pm 0.8 ; \%$ volatiles by weight: 4-7 (water); bulk density: $0.55 \mathrm{~g} / \mathrm{mL}$. CLS was used as a water solution at $40 \%$ working concentration.

Commercially available urea-formaldehyde (UF) resin with a solids content of $64 \%$, density of $1.29-1.31 \mathrm{~g} . \mathrm{cm}^{-3}$ at $20^{\circ} \mathrm{C}$, $\mathrm{pH}$ value of 8.5 , and a molar ratio (MR) of 1.16, was provided by the factory Kastamonu Bulgaria AD (Gorno Sahrane, Bulgaria).

Since the waste fibers were separated in a moist condition and contained a great number of cellulosic fibrils, they had to undergo a preliminary treatment before manufacturing the fiberboard composites. The pretreatment of waste fibers was performed by using a laboratory hammer mill (prototype, University of Forestry, Sofia, Bulgaria), shown in Figure 1.

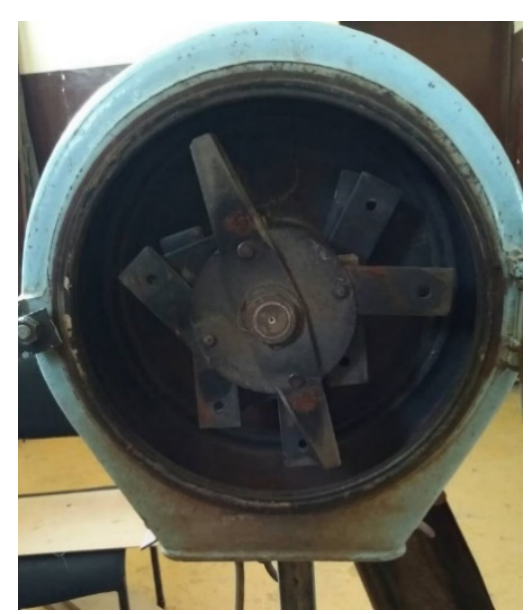

(a)

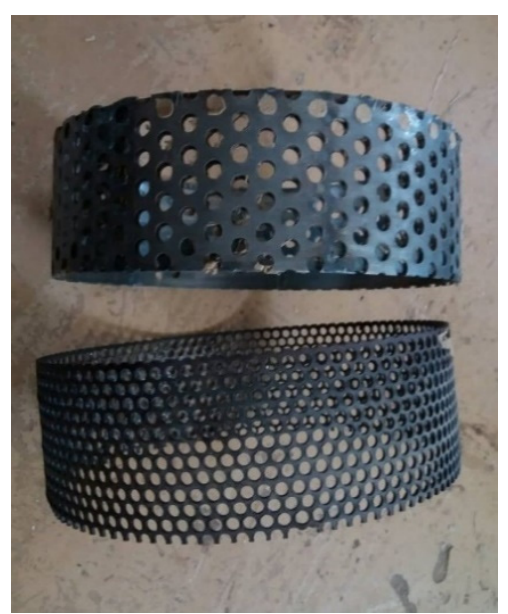

(b)

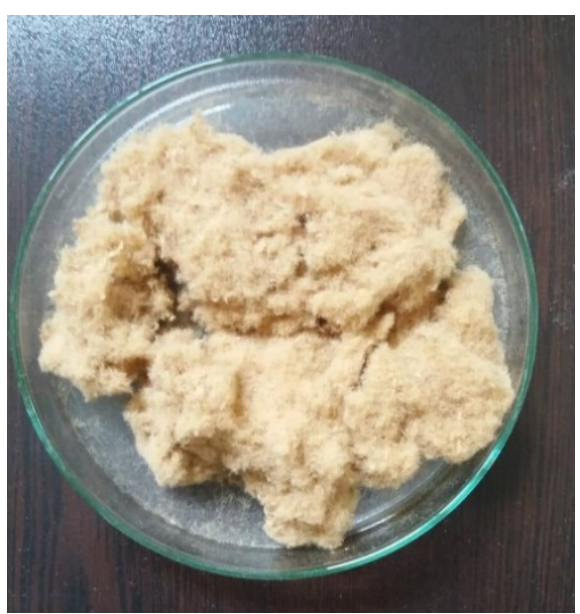

(c)

Figure 1. Prototype hammer mill used for preliminary treatment of residual wood fibers: (a) overview of prototype hammer mill; (b) hammer mill sieves, size $6 \mathrm{~mm}$ and $3 \mathrm{~mm}$; (c) residual fibers after pretreatment.

After the initial treatment, the bulk density of residual fibers was decreased to $17.47 \mathrm{~kg} \cdot \mathrm{m}^{-3}$.

Fiberboard panels were manufactured with dimensions $400 \mathrm{~mm} \times 400 \mathrm{~mm}$, a thickness of $6 \mathrm{~mm}$, and a target density of $750 \mathrm{~kg} \cdot \mathrm{m}^{-3}$. Four addition levels $(8 \%, 10 \%, 12 \%$, and $14 \%)$ of CLS as a binder, based on the dry fibers, were applied.

A control panel was produced with $10 \%$ UF resin content, based on the weight of dry fibers, and without CLS (panel REF10). This UF resin addition level (10\%) is typical for the commercially produced fiberboard panels. The UF resin was used at 50\% working concentration.

The manufacturing parameters of the laboratory-produced fiberboard panels are presented in Table 1. 
Table 1. Manufacturing parameters of fiberboard panels, produced from residual softwood fibers, bonded with CLS.

\begin{tabular}{ccccc}
\hline Panel Type & Adhesive Type & $\begin{array}{c}\text { Density } \\
\left(\mathbf{k g} \cdot \mathbf{m}^{-3} \mathbf{)}\right.\end{array}$ & $\begin{array}{c}\text { UF Resin } \\
\text { Content } \\
\mathbf{( \% )}\end{array}$ & $\begin{array}{c}\text { Calcium } \\
\text { Lignosulfonate } \\
\text { Content } \\
\mathbf{( \% )}\end{array}$ \\
\hline Type A & CLS & 750 & 0 & 8 \\
Type B & CLS & 750 & 0 & 10 \\
Type C & CLS & 750 & 0 & 12 \\
Type D & CLS & 750 & 0 & 14 \\
REF10 & UF & 750 & 10 & 0 \\
\hline
\end{tabular}

Waste softwood fibers were mixed with the CLS additive in a high-speed glue blender with needle-shaped paddles (prototype, University of Forestry, BG) at $850 \mathrm{~min}^{-1}$. The CLS or UF resin was sprayed in the laboratory blender through a $1.5 \mathrm{~mm}$ nozzle, followed by injecting a paraffin emulsion. The hot pressing process was carried out using a single opening hydraulic press (PMC ST 100, Italy). The press temperature was $200{ }^{\circ} \mathrm{C}$. The following four-stage pressing regime was applied: In the first stage, the pressure was increased to $4 \mathrm{MPa}(15 \%$ of the press cycle); in the second stage, it was gradually decreased to $1.2 \mathrm{MPa}(15 \%$ of the press time); in the third stage, the pressure was decreased to $0.8 \mathrm{MPa}(60 \%$ of the press time). The fourth pressing period was performed at a pressure of $1.5 \mathrm{MPa}\left(10 \%\right.$ of the press time). The press factor applied was $60 \mathrm{~s} . \mathrm{mm}^{-1}$. Following the hot pressing, the fiberboard panels were conditioned for 7 days at $20 \pm 2{ }^{\circ} \mathrm{C}$ and $65 \%$ relative humidity.

The physical and mechanical properties of the laboratory-produced panels (Figure 2) were determined in accordance with the European Standards EN 310, EN 317, EN 319, and EN 323 [106-109]. A precision laboratory balance Kern (Kern \& Sohn GmbH, Balingen, Germany) with an accuracy of $0.01 \mathrm{~g}$ was used to determine the mass of the test samples. The dimensions of the test specimen were measured using digital calipers with an accuracy of $0.01 \mathrm{~mm}$. The dimension stability (water absorption and thickness swelling) was measured after $24 \mathrm{~h}$ of immersion in water by the weight method [107]. The test samples were sanded before carrying out the tests. The mechanical properties (bending strength and modulus of elasticity) of the fiberboard panels were measured using a universal testing machine Zwick/Roell Z010 (Zwick/Roell GmbH, Ulm, Germany). For each property, eight test samples were used for testing.

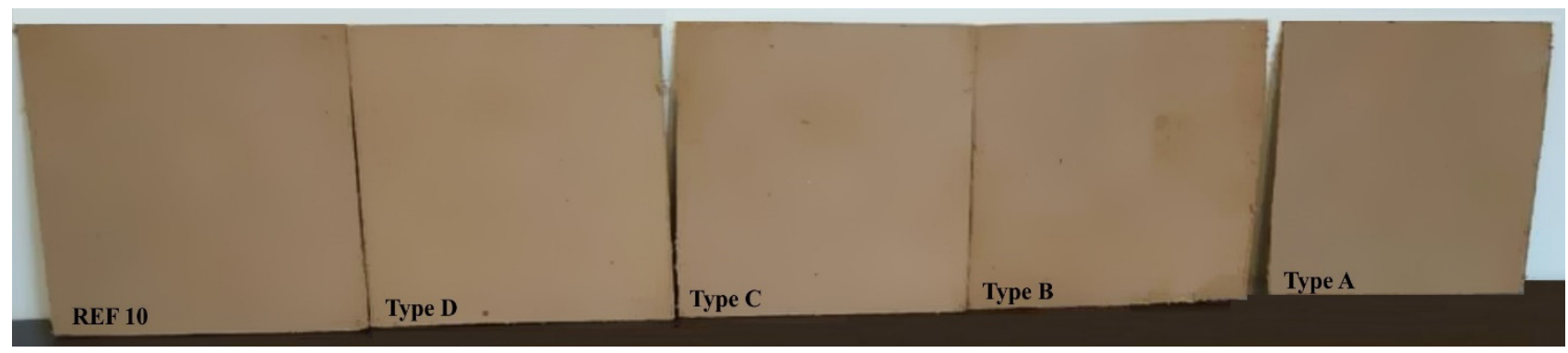

Figure 2. Fiberboard panels from residual softwood fibers from the pulp and paper industry, bonded with CLS; $750 \mathrm{~kg} \cdot \mathrm{m}^{-3}$ target density, $6 \mathrm{~mm}$ thickness, and four addition levels of ammonium lignosulfonate $(8 \%, 10 \%, 12 \%$, and $14 \%)$, and a control fiberboard panel (REF10), bonded with UF resin.

The formaldehyde content of the laboratory-produced panels was measured in the factory laboratory of Kronospan Bulgaria EOOD (Veliko Tarnovo, Bulgaria) on four test specimens in accordance with the standard perforator method EN 124,650 [110].

Variational and statistical analysis of the results was performed by using the specialized software QstatLab 6.0. One-way analysis of variance (ANOVA) was carried out 
to discern significant difference at $95 \%$ level of confidence, using SAS software program (version 9.2, 2010) (SAS, Cary, NC, USA). Grouping was then made between treatments using Duncan's multiple range test.

\section{Results and Discussion}

\subsection{Physical and Mechanical Properties}

The density of the laboratory-produced panels varied from 739 to $767 \mathrm{~kg} \cdot \mathrm{m}^{-3}$, rather close to the targeted value. The difference in this main characteristic of the fiberboards was significantly below $5 \%$; thus, it did not have a significant effect on the other physical and mechanical properties of the panels.

Water absorption (WA) and thickness swelling (TS) are important physical properties, strongly associated with the dimensional stability of wood-based panels $[27,28,111]$. Both properties were determined after $24 \mathrm{~h}$ immersion in water. A graphical representation of the WA ( $24 \mathrm{~h}$ ) of the laboratory-made fiberboard panels is presented in Figure 3. WA is not a standardized physical property; nevertheless, the WA after $24 \mathrm{~h}$ of fiberboard panels, varied from $223 \%$ to $123 \%$, i.e., a significant increase from approximately $148 \%$ in panel Type A ( $8 \%$ CLS) to $37 \%$ in panel Type D (14\% CLS), compared with the WA of the control panel (REF10), was found. Therefore, CLS, as a lignin-based, formaldehyde-free adhesive, will require a further chemical modification to increase its adhesion efficiency $[17,79,112]$. Increasing the CLS content from $8 \%$ to $14 \%$ resulted in a gradual decrease of WA of the samples of approximately $49 \%$.

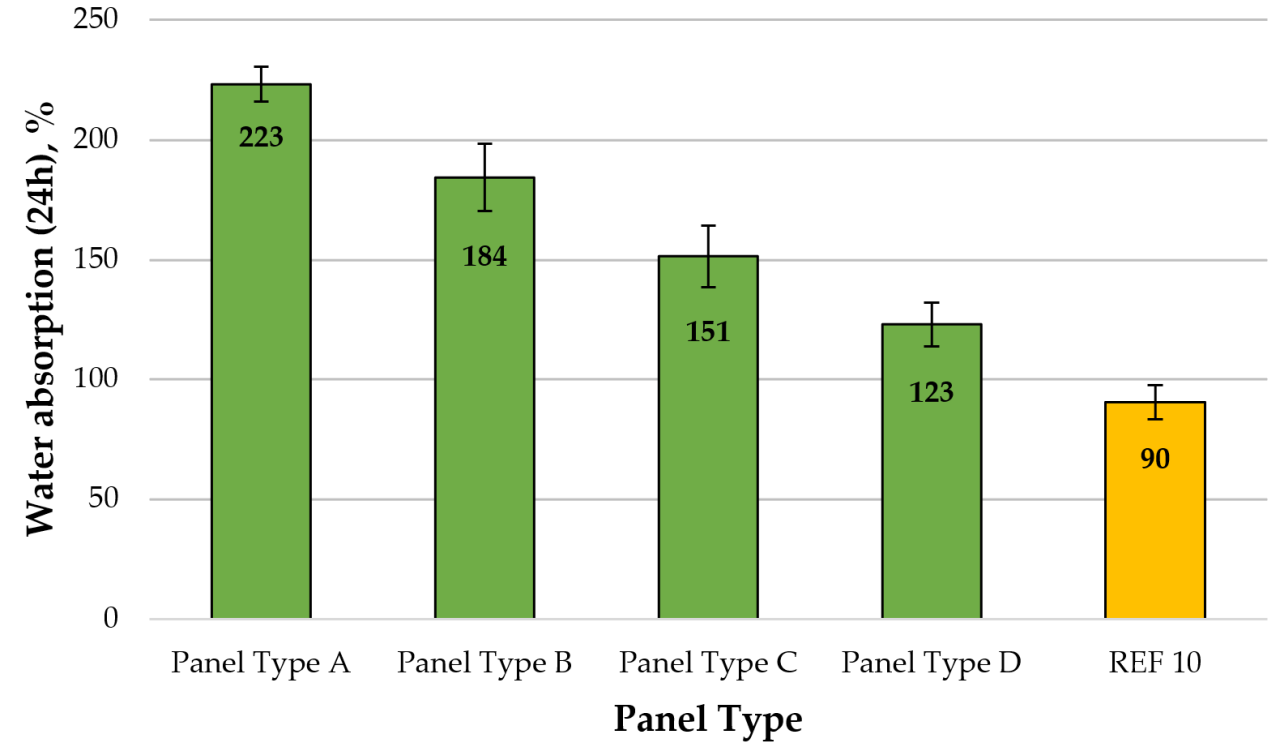

Figure 3. Water absorption ( $24 \mathrm{~h}$ ) of fiberboard panels produced: type A-8\% CLS; type B-10\% CLS; type C-12\% CLS; type D-14\% CLS, and REF10-10\% UF resin. (Error bar represents the standard deviation).

Comparable WA values of approximately $170 \%$ were achieved by $[17,81]$ for ecofriendly composites, comprised of recycled industrial wood fibers bonded with $15 \%$ content of magnesium lignosulfonate (MLS) as a binder, and veneered with beech veneers, also glued with MLS.

A graphical representation of the TS values $(24 \mathrm{~h})$ of the laboratory-produced fiberboard panels is shown in Figure 4. 


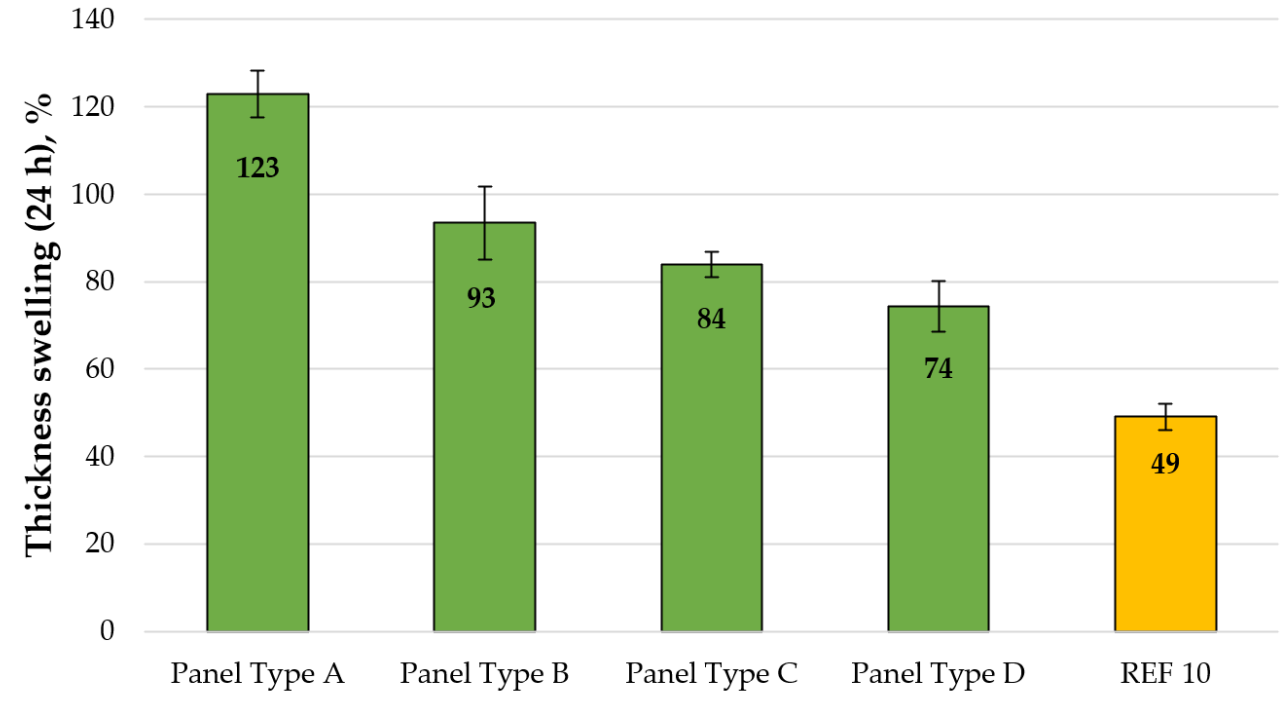

Panel Type

Figure 4. Thickness swelling ( $24 \mathrm{~h}$ ) of fiberboard panels produced: type A-8\% CLS; type B-10\% CLS; type C-12\% CLS; type D-14\% CLS, and REF10-10\% UF resin. (Error bar represents the standard deviation).

As seen in Figure 4, the laboratory-produced fiberboard panels, composed of industrial waste fibers bonded with CLS adhesive, exhibited very high TS values, ranging from $123 \%$ to $74 \%$, i.e., the values obtained were from 4.1 to 2.5 higher than the minimum limit to MDF panels for use in dry conditions (30\%), required by the standard EN 622-5 [113]. Even the control panel (REF10), manufactured from residual wood fibers bonded with $10 \%$ UF resin, had TS values, 1.6 times higher than the standard requirements. These very high TS values may be attributed to the significantly reduced lignin content of residual fibers $[17,81]$ and the characteristics of the CLS used as a bio-based adhesive [97,98]. The most significant improvement of TS values was determined when the CLS content was increased from $8 \%$ to $10 \%$.

In terms of mechanical properties, the modulus of elasticity (MOE) and bending strength (MOR) were tested.

A graphical representation of the mean MOE values of the laboratory-fabricated fiberboard panels is presented in Figure 5.

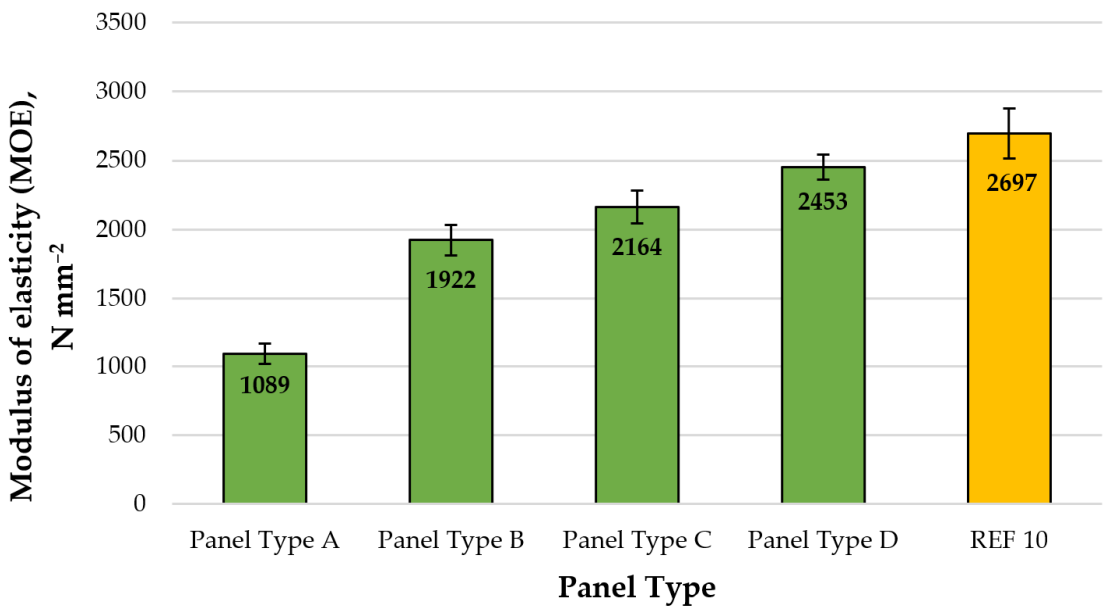

Figure 5. Modulus of elasticity (MOE) of fiberboard panels produced: type A-8\% CLS; type B-10\% CLS; type C-12\% CLS; type D-14\% CLS, and REF10-10\% UF resin. (Error bar represents the standard deviation). 
The fiberboard panels, bonded with CLS as an eco-friendly adhesive, exhibited MOE values, ranging from 1089 to $2453 \mathrm{~N} . \mathrm{mm}^{-2}$. The increased CLS addition from $8 \%$ to $14 \%$ resulted in improved MOE values by $125 \%$. Similar results were reported by [17] in their research on the development of eco-friendly composites produced from recycled wood fibers bonded with $15 \%$ MLS as a binder. None of the experimental fiberboard panels met the European standard requirements EN 622-5 [113] for MDF panels used in dry conditions $\left(\geq 2700 \mathrm{~N} . \mathrm{mm}^{-2}\right.$ ). The control fiberboard panel (REF10), fabricated with recycled fibers bonded with $10 \%$ UF resin, had 1.1 times higher MOE values than the panel, produced with $14 \%$ CLS as a binder (panel type D).

Finally, a graphical representation of the average MOR values of the laboratoryfabricated fiberboard panels is shown in Figure 6.

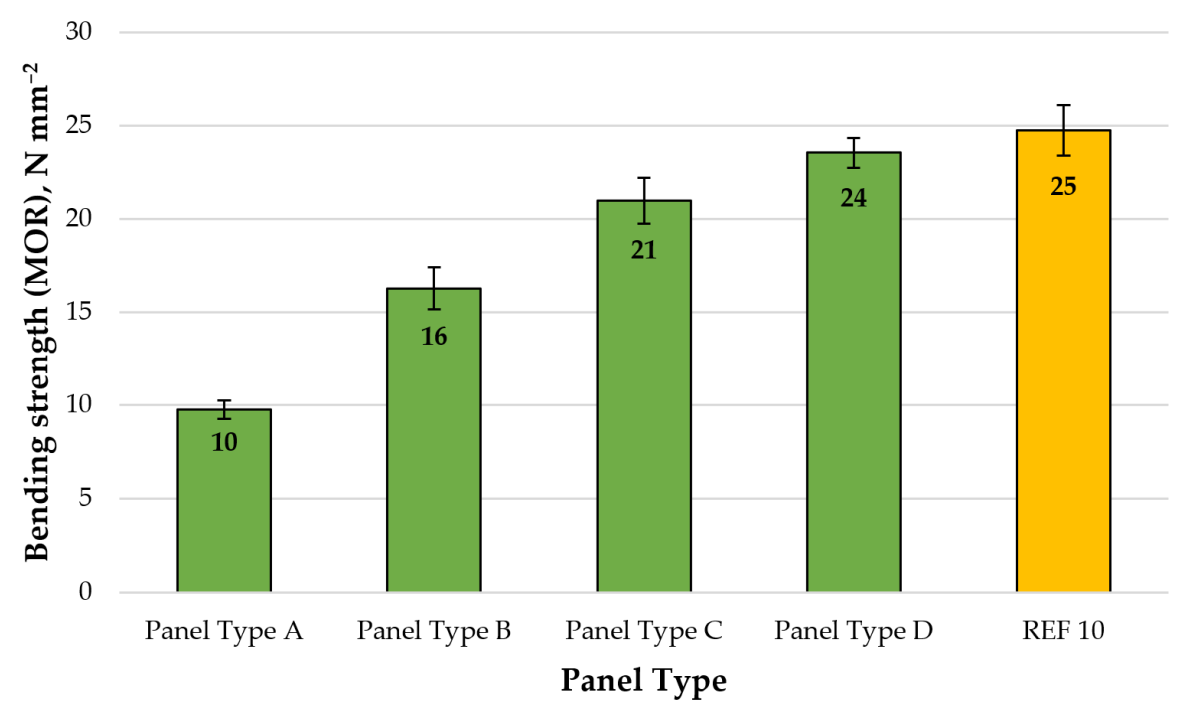

Figure 6. Bending strength (MOR) of fiberboard panels produced: type A-8\% CLS; type B-10\% CLS; type C-12\% CLS; type D-14\% CLS, and REF10-10\% UF resin. (Error bar represents the standard deviation).

The fiberboard panels exhibited MOR values, ranging from 10 to $24 \mathrm{~N} \cdot \mathrm{mm}^{-2}$. The increased CLS content from $8 \%$ to $14 \%$ resulted in improved MOR values by 2.4 times. The most significant improvement by $60 \%$ was determined when the CLS content was increased from $8 \%$ to $10 \%$. The panels bonded with $14 \%$ CLS (panel type D), met the standard requirement for MDF panels used in dry conditions $\left(23 \mathrm{~N} . \mathrm{mm}^{-2}\right)$ [113]. The

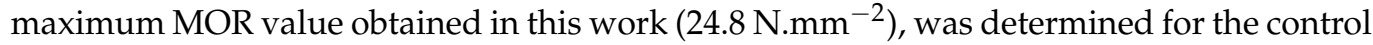
panel (REF10), bonded with 10\% UF resin. The fiberboard panel, bonded with the highest addition level of CLS (14\%), reached MOR values, relatively close to the control panel with a difference of $4 \%$ only. Antov et al. [98] concluded that MDF panels, complying with the European standard requirements, can be successfully produced with a very low phenolformaldehyde (PF) gluing factor of 3.5\% (based on the dry fibers) and CLS addition levels, varied from $5 \%$ to $15 \%$. In the same research, the maximum MOR values $\left(35.2 \mathrm{~N} . \mathrm{mm}^{-2}\right)$ were determined in MDF panels, fabricated with 5\% PF resin and 5\% CLS additive. This can be explained by the presence of phenolic and aliphatic hydroxyl groups in CLS, which increase the reactivity of lignin towards synthetic thermosetting resins [114].

Higher MOR and MOE values of the developed fiberboard panels could be achieved by covering their surfaces with veneers, melamine, high-pressure laminate, etc.

\subsection{Formaldehyde Content}

The results for the formaldehyde content of the laboratory-produced fiberboard panels, measured according the standard EN ISO 12460-5 (known as the perforator method) [110], are presented in Table 2. 
Table 2. Formaldehyde content of fiberboard panels, produced from residual softwood fibers bonded with CLS, according EN ISO 12460-5.

\begin{tabular}{ccccc}
\hline HDF Type & Adhesive & $\begin{array}{c}\text { UF Resin } \\
\text { Content } \mathbf{( \% )}\end{array}$ & $\begin{array}{c}\text { Calcium } \\
\text { Lignosulfonate } \\
\text { Content (\%) }\end{array}$ & $\begin{array}{c}\text { Formaldehyde } \\
\text { Content } \\
(\mathbf{m g} / \mathbf{1 0 0} \mathbf{g})\end{array}$ \\
\hline Type A & CLS & 0 & 8 & $1.1( \pm 0.1)^{1} \mathrm{~A}^{2}$ \\
Type B & CLS & 0 & 10 & $1.0( \pm 0.1) \mathrm{A}^{2}$ \\
Type C & CLS & 0 & 12 & $0.9( \pm 0.1) \mathrm{A}^{2}$ \\
Type D & CLS & 0 & 14 & $0.8( \pm 0.1) \mathrm{A}^{2}$ \\
REF10 & UF & 10 & 0 & $6.8( \pm 0.1) \mathrm{B}^{2}$ \\
\hline
\end{tabular}

${ }^{1}$ Standard deviation. ${ }^{2}$ Groupings based on Duncan's multiple range test, at $95 \%$ level of confidence.

It is clearly revealed from the data depicted in Table 2 that all types of panels bonded with CLS adhesive, namely type A to D, has low formaldehyde content and can be considered as zero formaldehyde content $[30,104]$. It is further reveled, that these values are significantly different with the value of the reference panel (REF10). Closer inspection of the data presented in Table 2, shows that the amount of CLS adhesive has no significant effect on formaldehyde content.

All laboratory-made fiberboard panels exhibited formaldehyde content values, fulfilling the requirements of the super E0 emission category $(\leq 1.5 \mathrm{mg} / 100 \mathrm{~g})$. The lowest free formaldehyde content of $0.8 \pm 0.1 \mathrm{mg} / 100 \mathrm{~g}$ was determined for panel Type $\mathrm{D}$, bonded with $14 \%$ CLS. The reference panel (REF10), manufactured from waste fibers bonded with $10 \%$ UF resin only, can be classified under the E1 emission grade ( $\leq 8 \mathrm{mg} / 100 \mathrm{~g})$. The results achieved are in accordance with our previous studies, where using different types of lignosulfonates in adhesive formulations for wood-based panels resulted in remarkably low formaldehyde content of the finished composites $[17,81,82,98]$. This might be attributed to the high amount of reactive phenolic and hydroxyl groups in CLS, which increase its reactivity towards formaldehyde $[97,98,114]$. Taking into consideration that natural wood releases low, but still detectable amount of formaldehyde, caused by its main polymeric constituents (cellulose, hemicellulose, and lignin) and extractives of approximately 0.5 to $2 \mathrm{mg} / 100 \mathrm{~g}$ [115-117], allows for defining the produced fiberboard panels, bonded with CLS as markedly low-emission wood-based panels.

\section{Conclusions}

Eco-friendly fiberboard panels with acceptable physical and mechanical properties in accordance with the European standards, with the exception of TS, and extremely low formaldehyde content, may be manufactured from residual wood fibers from the pulp and paper industry, bonded with CLS as a formaldehyde-free, lignin-based adhesive, applied at the content of $8 \%$ to $14 \%$, based on the dry fibers. The laboratory-fabricated panels, bonded with $14 \%$ CLS, exhibited MOR and MOE values, comparable with the minimum standard requirements for MDF panels used in dry conditions [113]. The formaldehyde content of the fiberboard panels bonded with various amount of CLS adhesive, tested in accordance with the perforator method [110], was remarkably low and significantly different with the value of the reference panel (REF10), ranging from $0.8 \mathrm{mg} / 100 \mathrm{~g}$ to $1.1 \mathrm{mg} / 100 \mathrm{~g}$, i.e., equal to formaldehyde release of natural wood, which allowed for their classification as eco-friendly wood-based panels. It is also found that the amount of CLS adhesive has no significant effect on formaldehyde content. According to their mechanical properties, the developed eco-friendly composites may be used in dry conditions for non-load bearing applications or as decorative panels.

Nevertheless, the significantly deteriorated dimensional stability, i.e., WA and TS, evaluated after $24 \mathrm{~h}$ immersion in water, represents the main drawback of the laboratoryproduced fiberboard panels. Future studies on using CLS in wood adhesive applications should be aimed at optimizing the production parameters, improving the CLS composition 
by adding appropriate cross-linkers, and extensively investigating the interaction processes between lignocellulosic fibers and lignosulfonate additives.

Author Contributions: Conceptualization, P.A., L.K. and V.S.; methodology, R.R.; validation, V.S.; investigation, V.S.; resources, A.N.P.; data curation, P.A., R.R. and A.N.P.; writing-original draft preparation, P.A. and L.K.; writing-review and editing, P.A. and A.N.P.; supervision, R.R. All authors have read and agreed to the published version of the manuscript.

Funding: This research received no external funding.

Institutional Review Board Statement: Not applicable.

Informed Consent Statement: Not applicable.

Data Availability Statement: The data presented in this study are available on request from the corresponding author.

Acknowledgments: This publication is also the result of the following projects implementation: Progressive Research of Performance Properties of Wood-Based Materials and Products (LignoPro), ITMS 313011T720, supported by the Operational Programme Integrated Infrastructure (OPII), funded by the ERDF, project No. НИС-Б-1002/03.2019 "Exploitation Properties and Possibilities for Utilization of Eco-friendly Bio-composite Materials", carried out at the University of Forestry (Sofia, Bulgaria), and projects by the Slovak Research and Development Agency under contracts No. APVV-18-0378, APVV-19-0269, APVV-17-0583 and VEGA1/0717/19.

Conflicts of Interest: The authors declare no conflict of interest.

\section{References}

1. Neykov, N.; Kitchoukov, E.; Simeonova-Zarkin, T.; Halalisan, A.F. Economic Efficiency Estimation of Innovations in Combined Forestry and Wood Processing Units in Bulgaria Through Certification in FSC Chain of Custody. In Innovation in Sustainable Management and Entrepreneurship; Prostean, G., Lavios Villahoz, J., Brancu, L., Bakacsi, G., Eds.; SIM 2019; Springer Proceedings in Business and Economics; Springer: Cham, Switzerland, 2020. [CrossRef]

2. Gregorzewska, E.; Sedliačiková, M.; Drábek, J.; Behún, M. Evaluating the international competetitiveness of Polish furniture manufacturing industry in comparison to the selected EU countries. Acta Fac. Xylologiae Zvolen 2020, 62, 149-164.

3. Sedliačiková, M.; Stroková, Z.; Klementová, J.; Šatanová, A.; Moresová, M. Impacts of behavioral aspects on financial decisionmaking of owners of woodworking and furniture manufacturing and trading enterprises. Acta Fac. Xylologiae Zvolen 2020, 62, 165-176.

4. Forest Product Statistics. Available online: http://www.fao.org/forestry/statistics/ (accessed on 5 February 2021).

5. Kim, M.H.; Song, H.B. Analysis of the global warming potential for wood waste recycling systems. J. Clean. Prod. 2014, 69, 199-207. [CrossRef]

6. Irle, M.; Privat, F.; Couret, L.; Belloncle, C.; Déroubaix, G.; Bonnin, E.; Cathala, B. Advanced recycling of post-consumer solid wood and MDF. Wood Mater. Sci. Eng. 2019, 14, 19-23. [CrossRef]

7. Ihnát, V.; Lübke, H.; Russ, A.; Borůvka, V. Waste agglomerated wood materials as a secondary raw material for chipboards and fibreboards. Part I. preparation and characterization of wood chips in terms of their reuse. Wood Res. 2017, 62, 45-56.

8. Lubis, M.A.R.; Manohar, S.; Laksana, R.; Fatriasari, W.; Ismayati, M.; Falah, F.; Solihat, N.; Sari, F.; Hidayat, W. The Removal of Cured Urea-Formaldehyde Adhesive Towards Sustainable Medium Density Fiberboard Production: A Review. J. Sylva Lestari 2021, 9, 23-44. [CrossRef]

9. Antov, P.; Savov, V. Possibilities for Manufacturing Eco-friendly Medium Density Fibreboards from Recycled Fibres-A Review. In Proceedings of the 30th International Conference on Wood Science and Technology-ICWST 2019 "Implementation of Wood Science in Woodworking Sector" \& 70th Anniversary of Drvna industrija Journal, Zagreb, Croatia, 12-13 December 2019; pp. $18-24$.

10. Lubke, H.; Ihnát, V.; Kuňa, V.; Balberčák, J. A Multi-Stage Cascade Use of Wood Composite Boards. Wood Res. 2020, 65, 843-854. [CrossRef]

11. Rammou, E.; Mitani, A.; Ntalos, G.; Koutsianitis, D.; Taghiyari, H.R.; Papadopoulos, A.N. The Potential Use of Seaweed (Posidonia oceanica) as an Alternative Lignocellulosic Raw Material for Wood Composites Manufacture. Coatings 2021, 11, 69. [CrossRef]

12. Taghiyari, H.R.; Majidi, R.; Esmailpour, A.; Sarvari Samadi, Y.; Jahangiri, A.; Papadopoulos, A.N. Engineering composites made from wood and chicken feather bonded with UF resin fortified with wollastonite: A novel approach. Polymers 2020, $12,857$. [CrossRef] [PubMed]

13. Grigoriou, A.H.; Ntalos, G.A. The potential use of Ricinus communis L. (Castor) stalks as a lignocellulosic resource for particleboards. Ind. Crops Prod. 2001, 13, 209-218. [CrossRef] 
14. Grigorov, R.; Mihajlova, J.; Savov, V. Physical and Mechanical Properties of Combined Wood-Based Panels with Participation of Particles from Vine Sticks in Core Layer. Innov. Woodwork. Ind. Eng. Des. 2020, 1, 42-52.

15. Küçüktüvek, M.; Kasal, A.; Kuşkun, T.; Erdil, Y.Z. Utilizing poppy husk-based particleboards as an alternative material in case furniture construction. BioResources 2017, 12, 839-852. [CrossRef]

16. Vis, M.; Mantau, U.; Allen, B. (Eds.) Study on the Optimised Cascading Use of Wood, No 394/PP/ENT/RCH/14/7689, Final Report; Publications Office: Brussels, Belgium, 2016; p. 337.

17. Antov, P.; Mantanis, G.I.; Savov, V. Development of Wood Composites from Recycled Fibres Bonded with Magnesium Lignosulfonate. Forests 2020, 11, 613. [CrossRef]

18. Eroglu, V.; Saatci, A.M. Reuse of sludge frompulp and paper industry pilot and full-scale applications. Water Sci. Technol. 1993, 28, 17-26. [CrossRef]

19. Ochoa de Alda, J.A.G. Feasibility of recycling pulp and pulp and paper sludge in the paper and board industries. Resour. Conserv. Recycl. 2008, 52, 965-972. [CrossRef]

20. Bajpai, P. Generation of Waste in Pulp and Paper Mills. In Management of Pulp and Paper Mill Waste; Springer: Berlin/Heidelberg, Germany, 2015; ISBN 978-3-319-11788-1.

21. de Alda, J.A.G.O.; Torrea, J.A. Applications of recycled paper mill effluents to wood substitutive products (RESPRO): Executive summary. Oppidum 2006, 2, 381-398.

22. Davis, E.; Shaler, S.M.; Goodell, B. The incorporation of paper deinking sludge into fibreboard. For. Prod. J. 2003, 53, 46-54.

23. Geng, X.; Deng, J.; Zhang, S.Y. Characteristics of pulp and paper sludge and its utilization for the manufacture of medium density fibreboard. Wood Fiber. Sci. 2007, 39, 345-351.

24. Migneault, S.; Koubaa, A.; Nadji, H.; Riedl, B.; Zhang, S.Y.; Deng, J. Medium-density fibreboard produced using pulp and paper sludge from different pulping processes. Wood Fiber. Sci. 2010, 42, 292-303.

25. Scott, G.M.; Smith, A. Sludge characteristics and disposal alternatives for the pulp and paper industry. In Proceedings of the International Environmental Conference, Atlanta, Georgia, 7-10 May 1995; Tappi Press: Atlanta, GA, USA, 1995 ; pp. $269-279$.

26. Simão, L.; Hotza, D.; Raupp-Pereira, F.; Labrincha, J.A.; Montedo, O.R.K. Wastes from pulp and paper mills-A review on generation and recycle alternatives. Cerâmica 2018, 64, 443-453. [CrossRef]

27. Youngquist, J.A. Wood-based composites and panel products. In Wood Handbook: Wood as an Engineering Material; USDA Forest Service, Forest Products Laboratory: Madison, WI, USA, 1999; pp. 1-31.

28. Kúdela, J. Surface properties of a medium density fibreboard evaluated from the viewpoint of its surface treatment. Acta Fac. Xylologiae Zvolen 2020, 62, 35-45.

29. Ferdosian, F.; Pan, Z.; Gao, G.; Zhao, B. Bio-based adhesives and evaluation for wood composites application. Polymers 2017, 9, 70. [CrossRef] [PubMed]

30. Mantanis, G.I.; Athanassiadou, E.T.; Barbu, M.C.; Wijnendaele, K. Adhesive systems used in the European particleboard, MDF and OSB industries. Wood Mater. Sci. Eng. 2018, 13, 104-116. [CrossRef]

31. Kumar, R.N.; Pizzi, A. Environmental Aspects of Adhesives-Emission of Formaldehyde. In Adhesives for Wood and Lignocellulosic Materials; Wiley-Scrivener Publishing: Hoboken, NJ, USA, 2019; pp. 293-312.

32. Wibowo, E.S.; Lubis, M.A.R.; Park, B.D.; Kim, J.S.; Causin, V. Converting crystalline thermosetting urea-formaldehyde resins to amorphous polymer using modified nanoclay. J. Ind. Eng. Chem. 2020, 87, 78-89. [CrossRef]

33. Pizzi, A.; Papadopoulos, A.; Policardi, F. Wood Composites and Their Polymer Binders. Polymers 2020, 12, 1115. [CrossRef] [PubMed]

34. Dae, P.B.; Woo, K.J. Dynamic mechanical analysis of urea-formaldehyde resin adhesives with different formaldehyde-to-urea molar ratios. J. Appl. Polym. Sci. 2008, 108, 2045-2051.

35. Kumar, R.N.; Pizzi, A. Urea-Formaldehyde Resins. In Adhesives for Wood and Lignocellulosic Materials; Wiley-Scrivener Publishing: Hoboken, NJ, USA, 2019; pp. 61-100.

36. Bekhta, P.; Sedliacik, J.; Saldan, R.; Novak, I. Effect of different hardeners for urea-formaldehyde resin on properties of birch plywood. Acta Fac. Xylologiae Zvolen 2016, 58, 65-72.

37. Jivkov, V.; Simeonova, R.; Marinova, A. Influence of the veneer quality and load direction on the strength properties of beech plywood as structural material for furniture. Innov. Woodwork. Ind. Eng. Des. 2013, 2, 86-92.

38. Bekhta, P.; Sedliačik, J.; Kačík, F.; Noshchenko, G.; Kleinova, A. Lignocellulosic waste fibers and their application as a component of urea-formaldehyde adhesive composition in the manufacture of plywood. Eur. J. Wood Prod. 2019, 77, 495-508. [CrossRef]

39. Pizzi, A. Urea and melamine aminoresin adhesives. In Handbook of Adhesive Technology, 3rd ed.; Pizzi, A., Mittal, K.L., Eds.; Taylor and Francis: New York, NY, USA, 2017; Chapter 10, pp. 283-320.

40. Tudor, E.M.; Barbu, M.C.; Petutschnigg, A.; Réh, R.; Krišt'ák, L. Analysis of Larch-Bark Capacity for Formaldehyde Removal in Wood Adhesives. Int. J. Environ. Res. Public Health 2020, 17, 764. [CrossRef]

41. Tudor, E.M.; Dettendorfer, A.; Kain, G.; Barbu, M.C.; Réh, R.; Krišt'ák, L. Sound-Absorption Coefficient of Bark-Based Insulation Panels. Polymers 2020, 12, 1012. [CrossRef]

42. Mirski, R.; Bekhta, P.; Dziurka, D. Relationships between Thermoplastic Type and Properties of Polymer-Triticale Boards. Polymers 2019, 11, 1750. [CrossRef]

43. US Consumer Product Safety Commission. An Update on Formaldehyde (Publication 725); US Consumer Product Safety Commission: Bethesda, MD, USA, 2013. 
44. Bekhta, P.; Sedliačik, J.; Noshchenko, G.; Kačík, F.; Bekhta, N. Characteristics of Beech Bark and its Effect on Properties of UF Adhesive and on Bonding Strength and Formaldehyde Emission of Plywood Panels. Eur. J. Wood Prod. 2021. [CrossRef]

45. World Health Organization. Formaldehyde, 2-Butoxyethanol and 1-tert-Butoxypropan-2-ol. In Monographs on the Evaluation of Carcinogenic Risk to Humans; International Agency for Research on Cancer: Lyon, France, 2006; Volume 88.

46. International Agency for Research on Cancer. IARC Classifies Formaldehyde as Carcinogenic to Humans; International Agency for Research on Cancer: Lyon, France, 2004.

47. Foti, D.; Voulgaridou, E.; Karastergiou, S.; Papadopoulos, A.N. Value-Added Wood Composites Made from Waste Polystyrene as a Binder: A Review. In Proceedings of the First International Conference on “Green" Polymer Materials [Online], 5-25 November 2020.

48. Kawalerczyk, J.; Siuda, J.; Mirski, R.; Dziurka, D. Hemp Flour as a Formaldehyde Scavenger for Melamine-Urea-Formaldehyde Adhesive in Plywood Production. BioResources 2020, 15, 4052-4064. [CrossRef]

49. Papadopoulou, E. Adhesives from renewable resources for binding wood-based panels. J. Environ. Prot. Ecol. 2009, 10, 1128-1136.

50. Nordström, E.; Demircan, D.; Fogelström, L.; Khabbaz, F.; Malmström, E. Green Binders for Wood Adhesives. In Applied Adhesive Bonding in Science and Technology; Interhopen Books: London, UK, 2017; pp. 47-71.

51. Hemmilä, V.; Adamopoulos, S.; Karlsson, O.; Kumar, A. Development of sustainable bio-adhesives for engineered wood panels-A review. RSC Adv. 2017, 7, 38604-38630. [CrossRef]

52. Hosseinpourpia, R.; Adamopoulos, S.; Mai, C.; Taghiyari, H.R. Properties of medium-density fiberboards bonded with dextrinbased wood adhesives. Wood Res. 2019, 64, 185-194.

53. Antov, P.; Savov, V.; Neykov, N. Sustainable Bio-based Adhesives for Eco-Friendly Wood Composites-A Review. Wood Res. 2020, 65, 51-62. [CrossRef]

54. Sarika, P.R.; Nancarrow, P.; Khansaheb, A.; Ibrahim, T. Bio-Based Alternatives to Phenol and Formaldehyde for the Pro-duction of Resins. Polymers 2020, 12, 2237. [CrossRef]

55. Saud, A.S.; Maniam, G.P.; Rahim, M.H.A. Introduction of Eco-Friendly Adhesives: Source, Types, Chemistry and Characterization. In Eco-Friendly Adhesives for Wood and Natural Fiber Composites; Composites Science and Technology, 2021; Jawaid, M., Khan, T.A., Nasir, M., Asim, M., Eds.; Springer: Singapore, 2021. [CrossRef]

56. Ghahri, S.; Bari, E.; Pizzi, A. The Challenge of Environment-Friendly Adhesives for Bio-Composites. In Eco-Friendly Adhesives for Wood and Natural Fiber Composites; Composites Science and Technology, 2021; Jawaid, M., Khan, T.A., Nasir, M., Asim, M., Eds.; Springer: Singapore, 2021. [CrossRef]

57. Costa, N.; Pereira, J.; Ferra, J.; Cruz, P.; Martins, J.; Magalhāes, F.; Mendes, A.; Carvalho, L.H. Scavengers for achieving zero formaldehyde emission of wood-based panels. Wood Sci. Technol. 2013, 47, 1261-1272. [CrossRef]

58. Costa, N.; Pereira, J.; Martins, J.; Ferra, J.; Cruz, P.; Magalhāes, F.; Mendes, A.; Carvalho, L. Alternative to latent catalysts for curing UF resins used in the production of low formaldehyde emission wood-based panels. Int. J. Adhes. Adhes. 2012, 33, 56-60. [CrossRef]

59. de Cademartori, P.H.G.; Artner, M.A.; de Freitas, R.A.; Magalhaes, W.L.E. Alumina nanoparticles as formaldehyde scavenger for urea-formaldehyde resin: Rheological and in-situ cure performance. Compos. B Eng. 2019, 176, 107281. [CrossRef]

60. Medved, S.; Gajsek, U.; Tudor, E.M.; Barbu, M.C.; Antonovic, A. Efficiency of bark for reduction of formaldehyde emission from particleboards. Wood Res. 2019, 64, 307-315.

61. Réh, R.; Igaz, R.; Krišt'ák, L.; Ružiak, I.; Gajtanska, M.; Božíková, M.; Kučerka, M. Functionality of beech bark in adhesive mixtures used in plywood and its effect on the stability associated with material systems. Materials 2019, 12, 1298. [CrossRef]

62. Mirski, R.; Kawalerczyk, J.; Dziurka, D.; Siuda, J.; Wieruszewski, M. The Application of Oak Bark Powder as a Filler for Melamine-Urea-Formaldehyde Adhesive in Plywood Manufacturing. Forests 2020, 11, 1249. [CrossRef]

63. Réh, R.; Krišt'ák, L.; Sedliačik, J.; Bekhta, P.; Božiková, M.; Kunecová, D.; Vozárová, V.; Tudor, E.M.; Antov, P.; Savov, V. Utilization of Birch Bark as an Eco-Friendly Filler in UF Adhesives for Plywood Manufacturing. Polymers 2021, 13, 511. [CrossRef]

64. Frazier, C.E. Isocyanate wood binders. In Handbook of Adhesive Technology, 2nd ed.; Pizzi, A., Mittal, K.L., Eds.; Marcel Dekker: New York, NY, USA, 2003; Chapter 33; pp. 681-694.

65. Hornus, M.; Via, K.B.; Gallagher, T.; Peresin, M.S. Partial substitution of pMDI with lignin containing cellulose nanofibrils: Low density oriented strand board. Wood Mater. Sci. Eng. 2020. [CrossRef]

66. Papadopoulos, A.N. Advances in Wood Composites. Polymers 2020, 12, 48. [CrossRef] [PubMed]

67. Papadopoulos, A.N. Advances in Wood Composites II. Polymers 2020, 12, 1552. [CrossRef] [PubMed]

68. Papadopoulos, A.N. Advances in Wood Composites III. Polymers 2021, 13, 163. [CrossRef]

69. Wang, Z.; Zhao, S.; Pang, H.; Zhang, W.; Zhang, S.; Li, J. Developing eco-friendly high-strength soy adhesives with improved ductility through multiphase core-shell hyperbranchedpolysiloxane. ACS Sustain. Chem. Eng. 2019, 7, 7784-7794. [CrossRef]

70. Papadopoulos, A.N.; Taghiyari, H.R. Innovative Wood Surface Treatments Based on Nanotechnology. Coatings 2019, 9, 866. [CrossRef]

71. Zhang, B.; Zhang, F.; Wu, L.; Gao, Z.; Zhang, L. Assessment of soybean protein-based adhesive formulations, prepared by different liquefaction technologies for particleboard applications. Wood Sci. Technol. 2020. [CrossRef]

72. Ghahri, S.; Pizzi, A. Improving soy-based adhesives for wood particleboard by tannins addition. Wood Sci. Technol. 2018, 52, 261-279. [CrossRef] 
73. Frihart, C.R.; Satori, H. Soy flour dispersibility and performance as wood adhesive. J. Adhes. Sci. Technol. 2013, $27,2043-2052$. [CrossRef]

74. Zhao, X.F.; Peng, L.Q.; Wang, H.L.; Wang, Y.B.; Zhang, H. Environment-friendly urea-oxidized starch adhesive with zero formaldehyde-emission. Carbohydr. Polym. 2018, 181, 1112-1118. [CrossRef] [PubMed]

75. Gu, Y.; Cheng, L.; Gu, Z.; Hong, Y.; Li, Z.; Li, C. Preparation, characterization and properties of starch-based adhesive for wood-based panels. Int. J. Biol. Macromol. 2019, 134, 247-254. [CrossRef] [PubMed]

76. Wedaïna, A.; Pizzi, A.; Nzie, W.; Danwe, R.; Konai, N.; Amirou, S.; Segovia, C.; Kueny, R. Performance of Unidirectional Biocomposite Developed with Piptadeniastrum Africanum Tannin Resin and Urena Lobata Fibers as Reinforcement. J. Renew. Mater. 2021, 9, 477-493.

77. Ndiwe, B.; Pizzi, A.; Tibi, B.; Danwe, R.; Konai, N.; Amirou, S. African tree bark exudate extracts as biohardeners of fully biosourced thermoset tannin adhesives for wood panels. Ind. Crops Prod. 2019, 132, 253-268. [CrossRef]

78. Santos, J.; Antorrena, G.; Freire, M.S.; Pizzi, A.; Álvarez, J.G. Environmentally friendly wood adhesives based on chestnut (Castanea sativa) shell tannins. Eur. J. Wood Prod. 2017, 75, 89-100. [CrossRef]

79. Hemmilä, V.; Adamopoulos, S.; Hosseinpourpia, R.; Sheikh, A.A. Ammonium lignosulfonate adhesives for particleboards with pMDI and furfuryl alcohol as cross-linkers. Polymers 2019, 11, 1633. [CrossRef] [PubMed]

80. El Mansouri, N.E.; Pizzi, A.; Salvadó, J. Lignin-based wood panel adhesives without formaldehyde. Holz Roh Werkst. 2006, 65, 65. [CrossRef]

81. Antov, P.; Jivkov, V.; Savov, V.; Simeonova, R.; Yavorov, N. Structural Application of Eco-Friendly Composites from Recycled Wood Fibres Bonded with Magnesium Lignosulfonate. Appl. Sci. 2020, 10, 7526. [CrossRef]

82. Antov, P.; Savov, V.; Krišt'ák, L.; Réh, R.; Mantanis, G.I. Eco-Friendly, High-Density Fiberboards Bonded with Urea-Formaldehyde and Ammonium Lignosulfonate. Polymers 2021, 13, 220. [CrossRef]

83. Chen, X.; Xi, X.; Pizzi, A.; Fredon, E.; Du, G.; Gerardin, C.; Amirou, S. Oxidized demethylated lignin as a bio-based adhesive for wood bonding. J. Adhes. 2020. [CrossRef]

84. Saražin, J.; Pizzi, A.; Amirou, S.; Schmiedl, D.; Šernek, M. Organosolv Lignin for Non-Isocyanate Based Polyurethanes (NIPU) as Wood Adhesive. J. Renew. Mater. 2021. [CrossRef]

85. Jiang, B.; Na, J.; Wang, L.; Li, D.; Liu, C.; Feng, Z. Reutilization of Food Waste: One-Step Extration, Purification and Characterization of Ovalbumin from Salted Egg White by Aqueous Two-Phase Flotation. Foods 2019, 8, 286. [CrossRef]

86. Jiang, B.; Wang, M.; Wang, X.; Wu, S.; Li, D.; Liu, C.; Feng, Z.; Li, J. Effective separation of prolyl endopeptidase from Aspergillus Niger by aqueous two phase system and its characterization and application. Int. J. Biol. Macromol. 2021, 169, 384-395. [CrossRef] [PubMed]

87. Jiang, B.; Wang, L.; Wang, M.; Wu, S.; Wang, X.; Li, D.; Liu, C.; Feng, Z.; Chi, Y. Direct Separation and Purification of alpha-Lactalbumin from Cow Milk Whey by Aqueous Two-phase Flotation of Thermo-Sensitive Polymer/Phosphate. J. Sci. Food Agric. 2021. [CrossRef] [PubMed]

88. Jiang, B.; Wang, X.; Wang, L.; Wu, S.; Li, D.; Liu, C.; Feng, Z. Fabrication and Characterization of a Microemulsion Stabilized by Integrated Phosvitin and Gallic Acid. J. Agric. Food Chem. 2020, 68, 5437-5447. [CrossRef]

89. Wang, Q.; Liu, W.; Tian, B.; Li, D.; Liu, C.; Jiang, B.; Feng, Z. Preparation and Characterization of Coating Based on Protein Nanofibers and Polyphenol and Application for Salted Duck Egg Yolks. Foods 2020, 9, 449. [CrossRef] [PubMed]

90. Masri, T.; Ounis, H.; Sedira, L.; Kaci, A.; Benchabane, A. Characterization of new composite material based on date palm leaflets and expanded polystyrene wastes. Constr. Build. Mater. 2018, 164, 410-418. [CrossRef]

91. Akinyemi, B.A.; Okonkwo, C.E.; Alhassan, E.A.; Ajiboye, M. Durability and strength properties of particleboards from polystyrene wood wastes. J. Mat. Cycles Waste Manag. 2019, 21, 1541-1549. [CrossRef]

92. Merino, M.; Saez, P.; Longobardi, I.; Astorqui, J.; Porras-Amores, C. Redesigning lightweight gypsum with mixes of polystyrene waste from construction and demolition waste. J. Cleaner Prod. 2019, 220, 144-151. [CrossRef]

93. Sharma, S.; Kumar, A. (Eds.) Lignin: Biosynthesis and Transformation for Industrial Applications; Springer Series on Polymer and Composite Materials, Switzerland AG; Springer Nature: Berlin/Heidelberg, Germany, 2020.

94. Solihat, N.; Sari, F.P.; Falah, F.; Ismayati, M.; Lubis, M.A.R.; Fatriasari, W.; Santoso, E.; Syafii, W. Lignin as an Active Biomaterial: A Review. J. Sylva Lestari 2021, 9, 1-22. [CrossRef]

95. Rico-García, D.; Ruiz-Rubio, L.; Pérez-Alvarez, L.; Hernández-Olmos, S.L.; Guerrero-Ramírez, G.L.; Vilas-Vilela, J.L. Lignin-Based Hydrogels: Synthesis and Applications. Polymers 2020, 12, 81. [CrossRef] [PubMed]

96. Bajwa, D.S.; Pourhashem, G.; Ullah, A.H.; Bajwa, S.G. A concise review of current lignin production, applications, products and their environmental impact. Ind. Crops Prod. 2019, 139, 111526. [CrossRef]

97. Klapiszewski, Ł.; Oliwa, R.; Oleksy, M.; Jesionowski, T. Calcium lignosulfonate as eco-friendly additive of crosslinking fibrous composites with phenol-formaldehyde resin matrix. Polymery 2018, 63, 102-108. [CrossRef]

98. Antov, P.; Savov, V.; Mantanis, G.I.; Neykov, N. Medium-density fibreboards bonded with phenol-formaldehyde resin and calcium lignosulfonate as an eco-friendly additive. Wood Mater. Sci. Eng. 2021, 16, 42-48. [CrossRef]

99. Jang, B.W.; Gläser, R.; Liu, C.; Jang, B.W.; Gläser, R.; Liu, C.; Capel-sanchez, M.C.; Campos-martin, J.M.; Fierro, L.G.; Sci, E.E.; et al. Fuels of the future. Energy Environ. Sci. 2010, 3, 253. 
100. El, R.; Brosse, N.; Chrusciel, L.; Sanchez, C.; Sannigrahi, P.; Ragauskas, A.; Pan, X.; Xie, D.; Yu, R.W.; Lam, D.; et al. Pretreatment of Lodgepole Pine Killed by Mountain Pine Beetle Using the Ethanol Organosolv Process: Fractionation and Process Optimization. Polym. Degrad. Stab. 2009, 94, 2609-2617.

101. Gellerstedt, G. Softwood kraft lignin: Raw material for the future. Ind. Crops Prod. 2015, 77, 845-854. [CrossRef]

102. Aro, T.; Fatehi, P. Production and Application of Lignosulfonates and Sulfonated Lignin. ChemSusChem 2017, 10, 1861-1877. [CrossRef] [PubMed]

103. Vishtal, A.G.; Kraslawski, A. Challenges in industrial applications of technical lignins. BioResources 2011, 6, 3547-3568. [CrossRef]

104. Pizzi, A. Recent developments in eco-efficient bio-based adhesives for wood bonding: Opportunities and issues. J. Adhes. Sci. Technol. 2006, 20, 829-846. [CrossRef]

105. Savov, V.; Antov, P. Engineering the Properties of Eco-Friendly Medium Density Fibreboards Bonded with Lignosulfonate Adhesive. Dr. Ind. 2020, 71, 157-162. [CrossRef]

106. EN 310. Wood-Based Panels-Determination of Modulus of Elasticity in Bending and of Bending Strength; European Committee for Standardization: Brussels, Belgium, 1999.

107. EN 317. Particleboards and Fibreboards-Determination of Swelling in Thickness after Immersion in Water; European Committee for Standardization: Brussels, Belgium, 1998.

108. EN 322. Wood-Based Panels-Determination of Moisture Content; European Committee for Standardization: Brussels, Belgium, 1998.

109. EN 323. Wood-Based Panels-Determination of Density; European Committee for Standardization: Brussels, Belgium, 2001.

110. EN ISO 12460-5. Wood-Based Panels-Determination of Formaldehyde Release-Part. 5. Extraction Method (Called the Perforator Method); European Committee for Standardization: Brussels, Belgium, 2015.

111. Shiag, K.; Negi, A. Physical and mechanical properties of MDF using needle punching technique. Int. J. Chem. Sci. 2017, 5, 2028-2030.

112. Laurichesse, S.; Avérous, L. Chemical modification of lignins: Towards biobased polymers. Prog. Polym. Sci. 2014, 39, 1266-1290. [CrossRef]

113. EN 622-5. Fibreboards—Specifications_Part. 5: Requirements for Dry Process Boards (MDF); European Committee for Standardization: Brussels, Belgium, 1998.

114. Hemmilä, V.; Hosseinpourpia, R.; Adamopoulos, S.; Eceiza, A. Characterization of Wood-based Industrial Biorefinery Lignosulfonates and Supercritical Water Hydrolysis Lignin. Waste Biomass Valor. 2020, 11, 5835-5845. [CrossRef]

115. Roffael, E. Volatile organic compounds and formaldehyde in nature, wood and wood based panels. Holz Roh Werkst. 2006, 64, 144-149. [CrossRef]

116. Athanassiadou, E.; Roffael, E.; Mantanis, G. Medium Density Fiberboards (MDF) from Recycled Fibres. In Proceedings of the Conference "Towards a Higher Technical, Economical and Environmental Standard in Europe" COST Action E31, Bordeaux, France, 29 September-1 October 2005; pp. 248-261.

117. Salem, M.Z.M.; Böhm, M. Understanding of formaldehyde emissions from solid wood: An overview. BioResources 2013, 8, 4775-4790. [CrossRef] 